\title{
Group Duties. Their Existence and Their Implications for Individuals
}

\author{
Stephanie Collins \\ Oxford: Oxford University Press, 2019, 218 or.
}

Betebeharren inguruko hausnarketa filosofikoa zerbait berria ez bada ere, azkenengo urteetan gero eta analisi filosofiko gehiago agertzen eta eztabaidatzen ari dira. Era berean, egungo ontologia sozialak «talde» moduko entitate sozialen ikerketa zaharra tresna sofistikatuagoekin eraberritu du. Erraza da betebeharrak eta entitate sozialak harreman estua dutela pentsatzea. Eta, hala ere, duela gutxi arte gehienbat bereizita aztertzeko kontutzat jo izan dira zenbait esparru akademikotan. Zorionez, sortzen ari den ikerketa multzo gero eta handiagoari erreparatuta (De Caro, Epstein eta Kelly 2019), bi kontu horiek elkargune bat osatzen ari dira gaur egun.

Elkargune horren adierazle ona dugu Collinsen urteetako hausnarketalanaren emaitza den liburu hau. Filosofiaren berezko zorroztasun analitikotik batere aldendu gabe, taldeen ontologiaren kontu normatiboen (batez ere moral eta politikoen) teorizaziora bideratua dago esplizituki. Eskaintzen dizkigun tresna kontzeptualak nolabait pentsamendu, hizkera eta praktika politikoa behintzat partzialki gidatzeko diseinatzen ditu, hitzaurrean esaten duen moduan.

Lanaren abiapuntua diskurtso politikoan maiz erabilitako entitateen («praktika-komunitateen») edo markoen («gobernantza-egituren») izaera ilun edota hutsalen presentzian datza; hots, krisi politiko gorien aurrean agertzen diren proposamenen osagaien izaera ilun edota hutsalean. Beste era batean esanda: zenbait egoera kritiko hobetu edo gainditzeari begira, zer-nolako entitate sozialak (espezifikoki, taldeak) lirateke beharrezko? Azken finean, guztiz antzua ez ezik arriskutsua ere balitzateke gauza ez den horri arazoen irtenbidearen misioa egoztea...

Egoztea, bai, egoztea. Hizkera arruntean edota literatura filosofikoan taldeak betebeharren eramailetzat jotzen ditugu. Ez dirudi, baina, kasu guztietan modu zilegian, edo behintzat ulergarrian, jotzen ditugunik halakotzat. Batetik, ez dagoelako beti argi zentzu kolektibo edo distributiboan hartzen 
ditugun eramailetzat. Adibidez: ${ }^{1}$ desjabetuon askapenak desjabetu ororen eta bakoitzaren gainean kokatzen al du betebehar kolektiboaren zati bat? Edo desjabetuen multzoa da, kolektibo gisa (ez halabeharrez haren kide guztien batuketa gisa), ustezko betebehar horren eramailea? Bestetik, eta agian funtsezkoagoa dena, taldeak denotatzerakoan ez dagoelako beti argi zer talde motaz ari garen. Iluntasun horrek taldeei praktikoki zer eska diezaiekegun jakitea oztopatzen du. Alta, talde mota batzuk gaitasun jakin batzuk dituztelarik soilik izango dira betebehar jakinen atribuziorako hautagai.

Beraz, lan honen muina talde moten bereizketan datza. Bereizketa, seinalatu den bezala, erabilgarria da betebehar-atribuzioen pertinentzia bereizteko. Bestalde, betebehar mota batzuk bereiztera eramango du. Eta, baita ere, talde mota baten edo bestearen kideentzako inplikazio normatiboak argitzera. Batetik, teoria oso bat du helburu (edozein talde mota azter dezakeena). Bestetik, entitate sozial horien betebeharrak izateko gaitasunean espezifikoki zentratzen den eredu bat lortzea bilatzen du: zein talde dira betebeharrak eramateko hautagai, zein ez. Horrela, egilearen helburuen artean talde-betebeharrentzako marko teoriko oso bat eskaintzea dago (talde txikietatik estatu edo «komunitate internazional»etaraino aplikagarria dena). Marko horren erabilgarritasuna edozein talde motak eskaintzen dituen kasuekin lantzeko gaitasunean datza. Horrela, iker daitezkeen taldeak ondo sailkaturik, kasu bakoitzean berezko betebeharrik baden edo ez jakin ahalko genuke, eta, baita ere, zer inplikazio atera beharko genituzkeen kasu bakoitzeko kideen betebeharrei dagokienez.

Jarraitu baino lehen, «betebehar» kontzeptuaren inguruko argibideren bat eman beharra dago. Betebeharrez hitz egiten duenean, Collinsek zentzu «prospektibo moral»ean erabiltzen du: betebeharren funtzioa etorkizunera bideratutako erabakitze-prozedurak elikatzea litzateke, erabakitze-prozedura horien input gisa. Zentzu horretan, nahiago du betebeharra erantzukizunetik bereizi, literatura filosofikoan maiz loturik agertzen badira ere. Goazen orain Collinsen estrategiaren igarobidetik pasatzera.

Zazpi atalez osaturik, ${ }^{2}$ lehendabizikoa dugu gainontzekoen egituratzaile, bertan «Hiruko Eredua» (The Tripartite Model) aurkezten zaigu eta. Eredu honen funtzioa goian aipatutako galdera motak argitzea edo interpretatzea litzateke. Hiru talde mota bereiziz, batez ere, argitu genezake egilearen aburuz zeintzuk liratekeen betebehar-eramaile eta horrek taldekideentzako zer-no-

1 Adibide hau ulertzeko, demagun momentu batez nolabaiteko komunistak garela eta, beraz, desjabetuen (talde gisa) askapena (horren esanahia hemen zehaztu behar izan gabe) betebehartzat («misio historikotzat») jotzen dugula.

2 Honako hauek dira horien izenburuak: 1. Hiruko Eredua; 2. Konbinazio eta koalizioen betebeharren aldeko argudioak; 3. Konbinazio eta koalizioen betebeharren aurka; 4 . Koordinazio-betebeharrak; 5. Konbinazioak eta koalizioak bereizten; 6. Kolektiboak eta euren betebeharrak; 7. Kidetasun-betebeharrak. 
lako inplikazioak lituzkeen. «Kolektiboak», «koalizioak», «konbinazioak»: ${ }^{3}$ horiek dira eredu honen hiru alderdiak, kategoriak. Lehenengoa, gainontzekoak ez bezala, agente-batuketa da, gogoeta moralei erreparatzeko potentziala daukana eta arrazoiaren arabera aritzen den talde mailako erabakitzeprozedurak dituena. Agente horiek (kideak) dira kolektiboa osatzen dutenak, eta prozedura horiek bermatzen dute bere batasuna. Bai koalizioei, bai konbinazioei talde mailako erabakitze-prozedurak falta zaizkie eta, hortaz, baita gogoeta moralei erreparatzeko pontentziala ere. Koalizioen kasuan, horiek osatzen dituzten agenteek helburu ezberdinak dituzte, nahiz eta gainontzeko agenteekin lan egiteko jarrera izan dezaketen, helburu partekatuak lortzeari begira. Azkenik, konbinazioak zenbait agente sortaz osatuta daude, baina ez dute ez kolektiborik ez koaliziorik osatzen.

Eredu honetatik zera erator daiteke segituan: koalizioek eta konbinazioek ez dute berezko betebeharrik (duties in their own right). Koalizioak eta konbinazioak ez dira, ez, betebeharren eramaile.

Bigarren eta hirugarren atalak osagarriak dira nolabait. Batetik, badira zenbait argudio egilearen jarreraren aurka; ${ }^{4}$ hau da, koalizio eta konbinazioen izaera betebehar-eramailea sostengatuko luketenak. Espazio-kontuengatik, lerro hauetan bigarren atalaren bukaeran erakusten den seigarren argudio bat komentatuko dut labur; egileak berak zintzoen, desafiatzaileen eta orokorrentzat jotzen du. Konbinazio eta koalizioak agente moraltzat jotzen dituena da. Argudioa zera litzateke: entitate bat agente morala baldin bada, orduan entitate hori betebeharrak eramateko hautagaia da; konbinazio eta koalizio batzuk agente moralak dira; beraz, konbinazio eta/edo koalizio batzuk betebeharrak eramateko hautagaiak dira. Collinsen estrategia bigarren premisaren aurka jotzean datza. Konbinazioak, bai, potentzialki agente moralak izan daitezke. Baina gaitasun hori ez da nahikoa betebeharrak eramateko. Koalizioen kasuan, eta literaturan topa daitezkeen beste eredu batzuen proposamena eztabaidatu ostean (bereziki, Bratman 2014 eta Gilbert 1989), agente-izaera kentzen die aipatutako egileek agentetzat hartzen dituzten kasu horiei («ekintza partekatuei» edo «subjektu pluralei», hurrenez hurren). Beraz, ezin dira agente moralak izan. Hau garrantzitsua da hurrengo atalari

3 Hiru talde mota horien aldea imajinatzeko, pentsa adibidez zer ezberdintasun dagoen «Italiako Alderdi Komunista»ren, «komunisten», eta «nazioarteko Alderdi Komunisten familia»ren artean. Kolektiboa, koaliazioa eta konbinazioa dira, hurrenez hurren:

(1) «Italiako Alderdi Komunistak faxismoaren eta okupazio naziaren aurka egiteko betebeharra dauka»; (2) «Komunistek ekoizpen-modu kapitalistaren gainditze iraultzailea dute betebehar gorentzat»; (3) «nazioarteko Alderdi Komunisten familiak Internazional Komunista egituratzeko betebeharra dauka».

4 Bost dira, bakoitza faktore batean oinarriturik: 1. Betebehar indibidualak; 2. Taldearen errumerezimendua; 3. Konbikzioak; 4. Giza eskubideak; 5. Exijentzia. 
begira, Collinsen aburuz, edozein betebeharren eramaile izateko, eramaileak agente izaera eduki behar du eta.

Hirugarren atalean «agentzia-printzipioa» aurkezten du, eta, ostean, «abilezia-argudioa» eta «erabakitze-argudioa» eztabaidatzera pasatzen da. Labur, «agentzia-printzipioa»k esaten diguna zera da: agente ez diren taldeek ezin dute betebeharrik eraman. Horrela, koalizio eta konbinazioen betebeharrak ukatzeko argudioa osa daiteke: printzipio horri agente izateko oinarrizko irizpidea gehitzen badiogu (hau da: erabakitze-prozedurarik ez duten taldeak ez direla agente), emaitza honako hau da: ez dago betebeharrik erabakitze-prozedurarik ez duten taldeentzako (beraz, ez dago betebeharrik ez koalizio, ez konbinazioentzako). Kapitulu hau, orokorrean, «agentzia-printzipioa» defendatzeari begira garatzen da. Horregatik, printzipio horri eusten diotelako dira erabilgarri bai «abilezia-argudioa», bai «erabakitze-argudioa». Lehenengoa bi premisak osatzen dute: 1. Entitate batek betebeharrak izatekotan, entitate horrek abileziaren bat dauka; 2. Agente ez diren taldeek ezin dituzte abileziak eduki. Finean, betebeharrak gaitasuna inplikatzen du, eta entitate batek betebeharrak baldin baditu, gaitasunen bat duelako izango da. Halere, argudio horrek ez dirudi nahikoa, behintzat agente ez diren taldeek abileziak izatea posible balitz (eta hala uste du Collinsek). Beraz, bestelako argudioren bat da beharrezko konbinazio eta koalizioek (agente ez diren talde motek) betebeharrik ez dutela baieztatzeko. Eta hori izango da «erabakitze-argudioa»k beteko duen funtzioa. Abilezia orokorrez haratago, gaitasun espezifiko bat egongo da orain jokoan: erabakitzeko ahalmena.

Betebeharren edukien gauzatzeak ongi morala bermatzen du, normalki jarrera erreaktibo jakinekin doana (gorespenarekin, adib.). Horrela, abilezian baino, betebeharrak betetzeko bestelako baldintza batean zentratu beharko genuke; hots, erabakiak hartzeko gaitasunean: betebeharrak betetzeko, entitate batek betebehar hori gauzatzeari begirako erabakiak hartzeko gaitasun zehatza erakutsi behar du. Agente ez diren taldeek ezin dituzte betebeharrak bete, ezin baitituzte erabakiak hartu. Beraz, zentzu honetan, konbinazioek edo koalizioek ezin dute betebeharrik ase.

Hemendik agente ez diren talde mota horiek inolako betebeharrik ez dutela eratorri beharko da? Egia esanda, ez... Laugarren atalean garatzen denez, badaude talde mota horiek bete ahalko eta beharko lituzketen errekerimenduak: zehazki, «koordinazio-betebeharrak». Horien funtzioa koalizio eta konbinazioen talde-betebeharren falta nolabait konpontzea litzateke. Errelebantzia morala duten arazo batzuek (pentsa dezagun aldaketa klimatikoan, kasu paradigmatiko gisa) errekerimenduak mahaigaineratzen dizkigute, nahiz eta agente den talde baten (hots, kolektibo baten) partaide ez izan (gizadiaren kideak, adib.). Zehazki, elkarlanean jartzeko errekerimenduak jartzen dituzte gure aurrean. Egoera mota horietan, sentikor (sensitive) izan daitezke bai koalizioen bai konbinazioen partaide diren kideak. Gaitasun hori izateko, kideek elkarrekin ekiten dute, besteak ere hauteman daitezkeen arrazoiekiko sen- 
tikorrak izango direlakoan. Sentikortasun hori arazo morala konpontzeko nahikoa izateko, «koordinazio-printzipioa» dena aplika daiteke. Printzipioaren muina zera da: kolektibo ez den talde bat moralki balioetsi dezakegun emaitza bat produzitzeko gai izatekotan, edo, are gehiago, emaitza hori produzituko duen kolektibo bat osatzeko gai izatekotan, orduan sentikor izateko betebeharra dauka edo kolektibizatzeko (kolektiboa osatzeko) betebeharra, hurrenez hurren. Behintzat ez badago modu hobean emaitza bera lor dezakeen hautagairik.

Hori bai, bosgarren atalean azaltzen den bezala, koordinazio-betebeharrei (sentikortasunari edo kolektibizazioari) begira, konbinazioak eta koalizioak bereiztea komeni da. Ezberdintasuna, batez ere, arrazonamendu-moduan datza. ${ }^{5}$ Koalizioen kasuan, adibidez, batek pentsatu behar du besteek ere indibidualki egin dezaketena egingo dutela. Hori ez da gertatzen, Collinsen aburuz, konbinazioen kasuan. Hemen, tamalez, ez baitago beti behin betiko erantzunik: ezin da beti jakin zer egin beharko lukeen batek. Bi pertsonak koalizio bat osatzen badute (hau da, helburu komunak baldin badituzte: itotzen ari den hirugarren bat lagundu, adib.), orduan bakoitza modu indibidualean ari da zenbait ekintza gauzatzeko beharrek bultzatuta, baina koalizio horren parte delarik arrazoituz. Konbinazioa balira, bakoitzak egiten duena besteak sentikortasunez ekingo duelako ustearen emaitza litzateke (ez baitituzte printzipioz helburu komunak partekatzen). Konbinazioekin jarraituz, Collinsek eskala handiko kasuekiko (berriz, aldaketa klimatikoa) eskasia praktikoa aitortzen du. Kasu horietan, konbinazio izatetik koalizio izatera modu sentikorrean eman beharko liratekeen pausoak eman beharko lirateke, hasteko behintzat. Aldeak garrantzitsuak dira ekintzari begira ere: koalizioan ekiten denean, errazagoa da elkarrekiko loturak sortzea.

Azkenengo bi atalak kolektiboei, horien betebeharrei eta kolektiboen kideen betebeharrei eskaintzen dizkie Collinsek. Seigarrenean, kolektiboen operazioak konbinazio eta koalizioekin alderatuta zertan ezberdintzen diren kontsideratzen du. Kolektiboen erabakiak hartzeko gaitasuna talde mailan gauzatzen da. Gainera, betebeharrak antzematen duen modu batean har daitezke erabaki horiek. Kolektibo izatea era askotan gauza daiteke: era demokratikoan edo diktatorialean, aristokratikoan edo kontsentsuz. Garrantzitsua zera da: kolektiboek modu indartsuan har ditzakete erabakiak talde-helburu jakinei begira, kontraesanik gabe eta moralitateren bat kontuan izanik. Bestalde, erabaki horiek kideen rol indibidualei aplikatzen zaizkie, betiere taldehelburuak gauzatzeari begira. Beraz, kolektiboetan, kideak rol atxikiak dituzten banakoak dira (gizabanakoak edo, kasu konplexuagoetan, beste kolektibo txikiagoak).

\footnotetext{
5 Koalizioen kideek, koordinazio-betebeharren aurrean, «koalizio-arrazoitzea» praktikatu beharko lukete: «gu-arrazoitze» mota bat, alegia. Konbinazioen kasuan, hori osaten duten kideek «ni-arrazoitzea» soilik praktikatu ahalko lukete.
} 
Bestalde, kolektiboen betebeharrak asetzeko orduan, kolektiboek euren erabakitze-prozedurak erabil ditzakete kideen gehitze soil batek produzitu ezingo lituzkeen emaitzak produzitzeko. Antolakuntzaren abantailak. Azkenik, kolektiboek aldeaniztasuna sor dezakete euren kideen artean. Aldeaniztasuna zera litzateke: kide guztiek euren ekarpena egiten dute efekturen bat produzitzeari begira egiten den ekintza-patroi batean. Berriz ere, kolektiboek ekiteak antolatzen dituzte. Kolektiboen betebeharrak ez dira, ez, kolektiboen kideen betebeharrak (ezberdintasun ontologikoa), baina kideen betebeharrak osatu egiten dituzte.

Zer inplikatzen du horrek kolektiboen kideen kasuan? Lehendabizi, kolektibo baten betebeharra betetzen ez denean, kide batzuen edo besteen gabeziarekin lotuko da (ezberdintasun ontologikoak ez baititu harreman kausalak desagerrarazten). Hori horrela izanik, kolektibo baten betebehar jakinak kideren baten betebeharrak inplikatzen ditu. Mota horretako taldeetan, taldearen betebeharrean kideen rolen erabilpenaren betebeharra dago inplikatua. Rolen erabilpena taldearen erabakiak hartzeko prozeduran inputak jartzera bideratua doa. Input horien ekarpena taldearen helburuak lortzeko nahikoak liratekeen rol-distribuzioei begira egingo litzateke: nahikoak taldearen prozedurek helburua lor dezaten. Rol-distribuzioa nahikoa izanik, kideek bakoitzaren rola erabiltzeko betebeharra dute.

\section{Erreferentziak}

BRATMAN, Michael. 2014. Shared agency: A planning theory of acting together. New York: Oxford University Press.

De Caro, Mario, Brian Epstein eta Erin Kelly. 2019. «Collective responsibility and social ontology». The Monist 102 (2): 131-33. https://doi: 10.1093/monist/onz001

GILBERT, Margaret. 2006. A theory of political obligation. Oxford: Oxford University Press.

SMiLey, Marion. 2017. "Collective responsibility». In Edward N. Zalta (arg.), The Stanford Encyclopedia of Philosophy. URL $=<$ https://plato.stanford.edu/archives/ sum2017/entries/collective-responsibility/>.

Zvonko Díaz

Universidad de La Laguna 